\title{
Three notions important for consecrated life: Christ-forming - the formation of persons - humility ${ }^{1}$
}

Presented below keywords-concepts have been prepared (in Polish) to the Encyclopedia of Pedagogical Axiology, Vol. 1-2, edited by prof. Assoc. Krystyna Chałas and Rev. Assoc. Adam Maj, prof. KUL, which will be released in Polish Publishing House by Peter and Joseph Wojcieszek, based in Radom (in the first quarter of 2016). Their content was part of the formation and pedagogical context of ongoing Year of Consecrated Life and the scientific conferences taking up the issue organized in the universal Church. Published in English they are promoting Polish theological thought, which can be of use in a broader research area.

\section{Christ-forming}

- term denoting a principle and formative process based on theological anthropology, assuming that a human person is created "in the image and similarity" of the Son of God and within ecclesial formation acquires the "form" of humanity revealed in Jesus Christ.

In the strict sense, this principle has intra-ecclesial (inside-Church) character, since the formation based on it does not refer to an ideal

$1 \quad$ Prezentowane niżej hasła-pojęcia zostały przygotowane (w języku polskim) do Encyklopedii Aksjologii Pedagogicznej, tom 1-2, pod red. prof. dr hab. K. Chałas i ks. dr. hab. A. Maja, prof. KUL, która ukaże się w Polskim Wydawnictwie Encyklopedycznym s.c. P. i J. Wojcieszek, z siedzibą w Radomiu (w pierwszym kwartale 2016 roku). Ich treść wpisuje się w kontekst formacyjno-pedagogiczny trwającego Roku Życia Konsekrowanego i organizowanych w Kościele powszechnym konferencji naukowych podejmujących to zagadnienie. Opublikowane w języku angielskim propagują polską myśl teologiczną, która może być spożytkowana w szerszym obszarze badawczym. 
verbalized evangelically or theologically, but is a process of shaping the interior life of a person (homo novus) in relation to the resurrected Christ (ie. living, not just historical), who finalizes the work of mankind redemption. In a broader sense it refers to every human being as a creature with a particular ontological status (homo religiosus).

Teologia duchowości

\section{Anthropological/theological aspect}

"Person" is an adequate term to denote a human being due to the fact that the human being cannot be reduced to an individual within its species, since it has in itself a particular ontological fullness'. The structure of his/her inner life markedly differs from other mammals and is not restricted to the biological/psychological dimension. "The person is a being for which love is the proper and full reference" ${ }^{3}$. It was already John Duns Scotus (+1308) who emphasised that a person develops properly only in ordine amoris, that is in the space of interpersonal relationships.

Among many other creatures, human being stands out through his/her status of an ontologically complex creature (perishable matter - immortal spirit) and through enjoying a particular relationship with God, who offers him/her two stages of life (earthly and eternal). Recognizing this ontological complexity presents many problems.

Man is to himself the most wonderful object in nature; for he cannot conceive what the body is, still less what the mind is, and least of all how a body should be united to a mind. This is the consummation of his difficulties, and yet it is his very being ${ }^{4}$.

Theology comes to aid, using the Revelation content to illuminate the mystery of man.

Now, man is not wrong when he regards himself as superior to bodily concerns, and as more than a speck of nature or a nameless constituent of the city of man. For by his interior qualities he outstrips the whole sum of mere things. He plunges into the depths of reality whenever he enters into his own heart; God, Who probes the heart, awaits him there; there he discerns his proper destiny beneath the eyes of God 5 .

2 Cf. K. Wojtyła, Miłość i odpowiedzialność [Love and Responsibility], TN KUL, Lublin 2001, p. 24.

Ibidem, p. 43.

B. Pascal, Pensees, no. 72, transl. by W.F. Trotter [no. 84 - Polish transl. T. BoyŻeleński, Warszawa 1989].

5

Pastoral Constitution on the Church in the modern world: Gaudium et spes, (7.12.1965), no. 14 . 
Therefore the Church accompanies man in his/her development, aware that "The Church cannot abandon man, for his 'destiny', that is to say his election, calling, birth and death, salvation or perdition, is

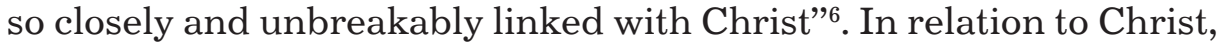
the mystery of man "truly takes on light", since He "fully reveals man to man himself and makes his supreme calling clear" "In this personal scheme man stops being an incomprehensible being to himself, especially when accepting this Love, "will make it his own" in a way"8. Finding here the meaning of life and starting a life participation in God's involvement with humanity, man gradually discovers his ontological identity, gazing at Him, who being the Divine Person "became a man" and followed every developmental stage typical of man in order to directly reveal this "mode of humanity," which expresses the original creative concept.

\section{Formative/spirituality aspect}

High dignity of man (resulting from the origin and calling) was compromised by $\sin$ (misterium iniquitatis), breaking the relationship with God and impeding the process of development towards the fullness of humanity. Due to this fact, man is not conceived in an optimally pure state, but inherits ontological blemish, which he can confront and gradually free himself of it through the process of development and education as well as auto-formation. Christian formation has a complex character, based on getting rid of sinful deformations (pars destruens) and acquiring moral and spiritual abilities (pars construens). The personal criterion for decisions in these areas is the Redemptor hominis, who initiated the process of man's re-forming, that is forming him anew.

A remarkable feature of this Divine-human process is "forming the person inside a person" (by analogy to the pre-natal period). St Paul speaks about gradual formation of Christ in the believers (cf. Gal 4:19). St. Augustine (+430) calls Our Lady the forma Dei (Sermo 208), in whom the Humanity of the Son of God was shaped, while St. Louis M. Grignion de Montfort (+1716) developed this thought, emphasizing that "saints are formed in Mary".

6 John Paul II, Redemptor hominis Encyclical Letter [Latin: The Redeemer of Man], (4.03.1979), no. 14 .

7 Gaudium et spes, no.22.

8 John Paul II, Redemptor hominis Encyclical, no.10.

$9 \quad$ See The Treatise of the Perfect Devotion to Our Lady, VII, 6. 
In the contemporary literature the term christoformisation was recalled and popularized by A. J. Nowak OFM (+2013), referring to the early Christian insight about christification of man or his Christ-like form. What is meant by the present usage is the purposeful effort of the Church towards every baptised person, aimed at configuring him or her to Christ. It was already Cyril of Alexandria (+444) who taught:

forms us according to his image, in such a way that the traits of his divine nature shine forth in us through sanctification and justice and the life which is good and in conformity with virtue [...] The beauty of this image shines forth in us who are in Christ, when we show ourselves to be good in our works ${ }^{10}$.

Anthony Nowak speaks about the process of progressive christoformisation $^{11}$, which brings out from man his natural abilities and integrating them with the power of grace, forms "full humanity" in him. This is done in the intra-personal space, in which two poles are discernible: Christ in man (Gal 4:19: until Christ be formed in you; Gal 2:20: nevertheless I live, yet not I, but Christ lives in me), and man in Christ (1P 5:14: peace be with you all that are in Christ Jesus). In this meaning earthly life of a believer has in a way a pre-natal character (in the Church-Mother), finally directed at being born to eternity, where Divine Persons exist in each other and open their unity to human persons. Such anthropology refers directly to the mystical dimension of personal life.

The Church taken in a personal way is one with Christ (una persona mistica), and her individual members are the members of the Mystical Body of Christ, accustoming themselves ontologically and functionally to undertake His mission towards mankind. This has been emphasised by L. Grignion de Montfort in relation to Mary:

Whoever has been put in the God's mould, he is at once formed in Jesus Christ and Jesus Christ in him. At a small cost and in a short time [...] it is necessary to destroy and melt the old Adam in oneself in order to become a new Adam (Christ) in Mary;

A. J. Nowak extends this sense to the Church. Ever, who has become a "new man" through baptism (here grace does not require the awareness of the recipient), undergoes an intensive formation of humanity, whose perfect image is found in Christ. Disposing of the heritage of the "old man" (natural and social burdens), in this place he introduces

$10 \quad$ Quote after: Veritatis splendour Encyclical, (6.08.1993), no. 73.

11 Cf.Psychologia eklezjalna [Ecclesial Psychology], ch.3, pp.110-159; See the same author Osobowość sakramentalna, Lublin 1992, 1997; Osoba-fakt i tajemnica, Rzeszów 2010. 
abilities and attitudes of the "new man", co-inherited with Christ (he was called New Man already by St Ignatius of Antioch, +107).

The process of christification (Christ-forming) involves more than imitating Christ or being a disciple understanding His ideas. It proceeds towards internal and external resemblance, which is achieved not just by human effort, but also by submitting one's existence to God, who do more inside man, "above all that we ask or think" (Eph $3: 20$ ). This is actualised effectively by sacramental life, where Christian pedagogy is contained within the option of "passing" (pascha) from the old to the new. The Paschal character of this process is realized in several significant stages of progressive christoformisation:

a) from the plane of religious life towards sacramental life (from homo religiosus to homo novus);

b) from excessive individualism to the sphere of communio personarum;

c) from the collective to the sphere of ecclesial life;

d) from the attitude of "have" to the priority of the "be" attitude (esse in Christo);

e) from heteronomic conscience (guilty according to law) to personal conscience (relationship to Person: I have sinned against you);

f) from the attitude of giving alms to one's neighbour (unwanted surplus) to loving Christ in every man (as I have loved you);

g) from trying to find meaning in value systems (various hierarchies) to finding it in the Incarnate Logos ( $\mathrm{Col} 2: 17$ : the reality is of Christ).

Even without entering the theological plane, it is possible to notice that each culture (the whole world) owes to Christ five fundamental, value-changing theses (L. Kołakowski): the superiority of love over law; absolute equality of all men; the principle that man shall not live by bread alone; abolishing the idea of a chosen nation; the belief that the world is organically imperfect ${ }^{12}$.

So, because of Christ man loses his central position in the world and, at the same time, regains it in another option.

\section{Person formation}

(Latin: formatio, formare - shape, form, model)

- complex and long lasting process directed at achieving a specified form in various ranges of a person's life. Formative effort has

12 Cf. L. Kołakowski, M. Machovec, Jesus - Modell des unbedingten Anspruchs an den Menschen, "Theologische Berichte” vol. 7 (1978), Zurich, p. 72-79. 
Teologia duchowości

intrapersonal character (auto-formation) and interpersonal one (mentors, ie. "formators" - the person undergoing formation) and also a multidimensional one through reference to many planes of the person and surrounding reality. It is based on the assumption that the person can develop abilities written into his/her genetic code or acquired, both internal and external, striving for a suitable "form" of humanity. It corresponds to the theological thought that we receive the gift of "being" from God as life already formed, not starting with something shapeless ${ }^{13}$.

Formation overlays the natural process of personal development and the social process of upbringing, introducing into this space, as the goal, "the full image of a person", toward which the efforts of a formed person and his/her tutors are directed, using suitable means. In this sense formation is always directed "at" (profession, marriage, prayer, apostolate, accepting suffering etc.) and is carried out "through" instruction, practice, endurance, faithfulness to ideals, forgiveness etc.

The formators' accompany and influence the formed person in a supportive way (inspiring and correcting), it is always at the service of the charge's development. Its essential elements include: proper diagnosis of the formed person's potential abilities, giving dynamics to interests and strengthening them, supporting in crisis or conflict situations, preparing for autonomy and social maturity. It is absolutely unacceptable - in view of human dignity - to manipulate the person's genetic endowment, his/her conscious decisions and free choices, aiming at accomplishing in the charge some "image of person" ideologically chosen by mentors (eg. mechanistic psychology, biologism, existential pessimism). The most adequate form of the "fullness of humanity", which could be realized in the mentored person, is not an "idea", but a "real ideal" achieved by a person (eg. the Humanity of Christ). This method of formation can be called iconic ${ }^{14}$. When the ideals which fascinate the formed person, are translated into self-fulfillment, the ambivalence of the mentors' function becomes evident. Inspirations and correcting decisions are then situated clearly in the relation: the formed person - the Icon Person, whose authority has an efficient impact. In particular, the experience of God's love "creates facts and changes life" 15 , yet personal effort in efficient "formation of the heart"16 is also necessary.

\footnotetext{
13 T. Paszkowska, Formacja i godność [Formation and dignity], Kraków 2004, p. 8.

14 The term used by A. Siemieniewski and Jan Paweł II, Letter to the Priests for Holy Thursday 2002; Exhortation Vita consecrata, no. 14.
} 
In the formation process several stages can be distinguished (eg. initial, progressive, concluding), without breaching the assumption that it is a permanent process.

By differentiating, through additional terms, several formation processes are usually indicated, criss-crossing inside a person and overlaying each other:

1. Human formation - it refers to the natural potential of the person (genetic, acquired through upbringing or personal effort) and the dignity of the person, implying duties towards oneself and the others.

Among various values, a human person has a clear priority in his/her dignity, one also accepts responsibility for the shape and style of one's life. On this formative plane the sense of one's own dignity develops, as well as the sense of value, responsibility, meaning of life and activity. There is also the formation of intellect, will and emotional responses. Objects of personal effort include: personality development (in the intellectual, emotional, volitional aspect); acquiring specific attitudes (ethical, moral, social, religious); shaping the character through achieving difficult goals, connected with a "high measure of life" chosen for oneself ${ }^{17}$.

When a person comes to this world, he or she "is given to him/herself in some kind of an initial stage, is an outline for a future picture," and when he/she clasps this state tightly (an unfulfilled one), the horizons are limited and the person loses him/herself. By opening to reality and undertaking its challenges - creating various works, serving high ideas, being devoted to people - "the person becomes oneself more fully and in reality"18.

2. Social/cultural formation - it has cultural values as its object (man as a recipient and creator of culture in many areas), as well as professional ones (professionalism, flexibility, involvement, efficiency, innovativeness etc.) and social obligations (eg. military service, cofinancing common good through taxes). The formative role is fulfilled here by educational system, specific cultural institutions, companies, legal system (administrative, penal etc.), models accepted in the concrete culture or local community.

It is indispensable to achieve a suitable personal distance in the area of social ideologies to evaluate them properly and to be a conscious participant. For example, in the essence of modern materialism one should discern the subtlety, which does not negate the spirit directly, but states that

17 Cf. John Paul II, Apostolic Letter Tertio millenio adveniente, (10.11.1997), no. 31.

18 R. Guardini, Bóg daleki. Bóg bliski, transl. J. Koźbiał, Poznań 1991, p. 269-270. 
matter comes first, is the source; in the beginning there is matter, not Logos. From this matter everything develops in a process of incidences, which becomes a process of necessity. The spirit is always a product of the matter [...] The spirit is transformed by restructuring its material conditions [...], mechanically, through changing or creating structures. The core of the contemporary materialism is usurping for oneself the ability to create a perfect man and perfect humanity by creating structural recipes and this core has proved to be a mistake ${ }^{19}$.

3. Spiritual or religious formation - it has the spiritual dimension as its object, proper for the human person, related to originating from God and the call to eternal life. Human spirit is shaped also within human and social formation, but it has its own specific quality and requires formation in this unique area.

At the heart of the world there dwells the mystery of man discovering himself to be God's son in the course of a historical and psychological process in which constraint and freedom as well as the weight of sin and the breath of the Spirit alternate and struggle for the upper hand ${ }^{20}$.

In the case of Christians evangelical values are meant, logically connected with faith, which are the personal and communal ideal of the believers, shaping their beliefs and attitudes, forming the conscience and giving direction to callings. "The Redemptor hominis cannot fail to be the Re-formator of man, who, before being subject to de-formation - was wonderfully formed by the Creator in his image and similarity"21.

All ways of life in the Church - laity, clergy, consecrated persons undertake formation proper for themselves, closely integrated with the spirituality of the concrete way ${ }^{22}$.

3a) Formation of laity - is based on the responsibility of a baptised person for their faith and life. There must be a

personal responsibility for formation: this, in fact, is essentially a "formation of self". In addition, there is the conviction that at one and the same time each of us is the goal and principle of formation. [...] I $\mathrm{t}$ is particularly important to know that the work of formation, while having

19 J. Ratzinger, Czas przemian w Europie. Miejsce Kościoła $i$ świata [The Time of change in Europe. The place of the Church and the World], transl. M. Mijalska, Kraków 2005, p. 75-76. 77.

Paul VI, Apostolic Letter Octogesima adveniens, (14.05.1971), no. 37. Truth and Love. Ethical reflections], Lublin 1995, s. 325. 
intelligent recourse to the means and methods available from human science, is made more effective the more it is open to the action of God ${ }^{23}$.

This formation is based here on the spirituality of baptismal participation in the death and resurrection of Christ. It is not enough to enrich personality through ascesis, mortifying what is not decent for man, it is necessary to have the pars construens of formation, that is being configured to Christ ${ }^{24}$. This formation, determined by grace takes out from the "old man" the whole Man ("a new man"), the efforts related to this are the pedagogy of holiness ${ }^{25}$, they deepen the kerigma, responding to the "desire for the infinite which abides in every human heart" 26 and connect the formation to the "way of beauty" (via pulchritudinis), which facilitates conveying the faith ${ }^{27}$. In this pedagogy, "which will introduce people step by step to the full appropriation of the mystery" and to free and responsible decisions there must be much time and patience ${ }^{28}$.

3b) Formation of presbyters - it includes first the seminary time, then

because of the circumstances particularly of contemporary society, must it be pursued and perfected even after the completion of the course of studies in seminaries [...] the younger clergy would be gradually introduced into the priestly life and apostolic activity, under its spiritual, intellectual, and pastoral aspects, and would be able, day by day, to renew and foster them more effectively ${ }^{29}$.

Doing their ministry, if they remain

open to the Spirit of Christ, who gives them life and direction. By the sacred actions which are theirs daily as well as by their entire ministry which they share with the bishop and their fellow priests, they are directed to perfection in their lives ${ }^{30}$.

23 John Paul II, Apostolic Exhortation of the Lay Faithful in the Church and in the World: Christifideles laici, (30.12.1988), no. 63.

See term: Christoformisation; and A. Vergote, Jezus Chrystus jako fundament wychowania, „Communio” 11(1991) nr 2, s. 89-97.

John Paul II, Apostolic Letter Novo millennio ineunte, [English: At the beginning of the new millennium], (6.01.2001), no. 31.

Francis, Apostolic Exhortation on the proclamation of the Gospel in today's world: Evangelii gaudium, [English: The Joy of the Gospel], (24.11.2013), no. 165.

See ibid., no. 167.

See ibid., no. 171.

Decree on priestly training: Optatam totius, (28.10.1965), no. 22 .

Decree on the ministry and life of priests: Presbyterorum ordinis, (7.11.1965), no. 12. 
Both diocesan and religious presbyters "should strive during the whole course of their lives to perfect the culture they have received in matters spiritual and in arts and sciences" ${ }^{31}$. In a similar degree "permanent formation is an intrinsic requirement" in relation to bishop, "his vocation and mission"32; for this purpose special courses are organized, as well as yearly meetings of bishops in their initial years, days of study and renewal through spiritual exercises. In the case of every man who was ordained the idea is to be "configured to Christ, the Head and Shepherd" of the whole Mystical Body as well as to acquire pastoral love ${ }^{33}$. Different dimensions of priestly formation aim at shaping "balanced people, strong and free, capable of bearing the weight of pastoral responsibilities" and sustain relationships with others ${ }^{34}$. It is equally important to have emotional maturity and capacity for abstinence connected with celibacy, connected with the "formation to liberty", which can enable one to be a master of himself 35 . The whole is completed by "spiritual formation", leading to a deep intimacy with $\mathrm{Christ}^{36}$. Intellectual formation has also a clear practical meaning, resulting in the "understanding of faith" 37 , as well as the pastoral one, fortifying the ability to using everything for the good of the God's People ${ }^{38}$. Finally, permanent formation is an indispensable aid to overcome the temptation of "reducing his ministry to an activism which becomes an end in itself, to the provision of impersonal services" and guarding with a vigilant love the "mystery" which was entrusted to him for the good of the Church and humanity.

3c) Formation of consecrated persons - concerns their radical decision, expressed in public vows, to undertake life "after Christ" poor, obedient and chaste, in a charismatic community of people acknowledged by Church authorities. Devoting one's life to God aims at making the person holy and at undertaking mission towards the others in the world.

31 Decree on the adaptation and renewal of religious life: Perfectae caritatis, (28.10.1965), no. 18.

John Paul II, Apostolic Exhortation on the bishop servant of the Gospel of Jesus Christ: Pastores gregis, (16.10.2003), no. 24.

John Paul II, Apostolic Exhortation on the Formation of Priests in the Circumstances of the Present Day: Pastores dabo vobis, (25.03.1992), no. 21n.

Ibidem, no. 43.

35 Cf. ibidem, no. 44.

Ibidem, no. 45-50.

37 Cf. ibidem, no. 51-56.

38 Ibidem, no. 51-59. 
As a consequence, the life of consecrated person is "a path of gradual identification with the attitude of Christ towards the Father"39, lasting for the whole life and involving the whole person, heart, mind and will (Matt 22:37). Formation is here not only

a teaching period in preparation for vows but also represents a theological way of thinking of consecrated life which is in itself a never ending formation "sharing in the work of the Father who, through the Spirit, fashions in the heart the inner attitudes of the Son" $"$

From the human side, initiating this process of taking on the thoughts and feelings of Christ is integrated with the acquired theological, human and technical knowledge, as well as with spiritual and apostolic life proper for the institute ${ }^{41}$. A principle characteristic for the economy of salvation is

the transformation of the entire cosmos through the heart of man, from within [...] In the economy of the Redemption the evangelical counsels of chastity, poverty and obedience constitute the most radical means for transforming in the human heart this relationship with "the world": with the external world and with one's personal "I" - which in some way is the central part "of the world" in the biblical sense, if what "does not come from the Father" begins within $i^{42}$.

The effectiveness of formation is

linked to the ability to establish a method characterized by spiritual and pedagogical wisdom [...] individuals are converted to the Word of God in the depths of their being and, at the same time, learn how to discover the signs of God in earthly realities ${ }^{43}$.

The formative effort must

have a profound effect on individuals, so that their every attitude and action, at important moments as well as in the ordinary events of life, will show that they belong completely and joyfully to God ${ }^{44}$.

$39 \quad$ John Paul II, Apostolic Exhortation on the Consecrated Life and its Mission in the Church and in the World: Vita consecrata, (25.03.1996), no. 65.

40 Congregation for Institutes of Consecrated Life and Societies of Apostolic Life, Instruction: Starting Afresh from Christ: A Renewed Commitment to Consecrated Life in the Third Millennium, (19.05.2002), no. 15.

Cf. ibidem, no. 18.

John Paul II, Apostolic Exhortation to Men and Women Religious on Their Consecration in the Light of the Mystery of Redemption: Redemptionis donum, (25.03.1984), no. 9.

Exh. Vita consecrata, no. 68.

Ibidem, no. 65 . 
Consecrated persons undertake a task - for the Church and the world - consisting in showing

that the Incarnate Son of God is the eschatological goal towards which all things tend, the splendour before which every other light pales, and the infinite beauty which alone can fully satisfy the human heart. Consecrated life, then [...] is the matter of living and expressing this by conforming one's whole existence to Christ in an all-encompassing commitment which foreshadows the eschatological perfection ${ }^{45}$.

A precious fruit of permanent formation is the everyday ability to live out one's calling as a gift always new and treasured ${ }^{46}$.

In conclusion, it should be stressed that in formation man is taken as a person in his idem and in his ipse. In the idem dimension - pointing to his identity - he always remains "himself". In the ipse dimension - emphasizing subjectivity - man is not always "the same." Paradoxically, he is "always himself" precisely to the extent he is "not the same" in his development and activity ${ }^{47}$.

\section{Humility}

\section{(Greek: tapeinosis, Latin: humilitas)}

- virtue (spiritual skill) and external attitude, affirming the truth about one's own limitedness, expressed in one's meekness towards God and lack of haughtiness towards people. A humble person is free of vanity, producing resentment and boastfulness of one's own skills or achievements. He or she finds a proper measure for self-assessment, being ready to accept recognition, without lingering over it, but focusing on future goals instead. He/she acts independently of opinion, underassessment or envy; him/herself praises the others willingly (an authentic act of humility - J. Woroniecki $\mathrm{OP}^{48}$ ).

Among biblical characters, Moses is considered the humblest of people (Num 12:3) and the mysterious Servant of Jahwe, who realizes God's plans in obedience, is a very special model of humility (Is

Ibidem, no. 16.

Instruction Starting Afresh from Christ, no. 15.

Cf. I. Sanna, L’antropologia tra modernitá e postmodernitá, Brescia 2001, s. 352.

See M. J. Kempys, Rola cnót moralnych $w$ dążeniu do petni człowieczeństwa $w$ świetle pism o. Jacka Woronieckiego, [The role of the moral virtues in the pursuit of full humanity in the light of the writings of Jacek Woroniecki], Kraków 2005; M. Zawada, Podstawy architektury duchowej. Pokora, [Basics of spiritual architecture. Humility], Kraków 2006. 
53:4-10). Wisdom books teach: "The greater you are, the more you must humble yourself; so you will find favour in the sight of the Lord" (Sir 3:18; cf. Dan 3:39: in spiritu humilitatis). The Creator is "the Good of the humble" (Judith 9:11n) and the Messiah - "quiet and of humble heart" (Matt 11:29), who meekly washes his disciples' feet (Jn 13:14nn) and teaches by his own example, how they should treat each other. "Being clothed in humility" (cf. 1P 5:5; Col 3:12) they should care for the other person's good, choosing the last place for themselves. Voluntary lowliness attracts God's gaze and results in graces. Mary's Magnificat highlights this experience (cf. Lk 1:46-49: "he has looked with favor on the lowliness ... the Mighty One has done great things for me..."). Also in trouble, the humble one will meet God's look and support ${ }^{49}$.

The practice of humility is connected with the awareness of one's own sinfulness, so having constantly in mind one's past sins supports the conviction that sin is a deep evil ${ }^{50}$. Because of this, a humble person is submissive towards people who admonish him/her and receives good counsel with gratitude ${ }^{51}$. St. Augustine considers the first step of humility to be the listening "in lowliness the words of truth", remembering them and putting into practice $^{52}$. In this way the process of ascending to heaven begins, also closely connected with the fear of God, which leads to perfect charity, driving away all slavish fear of God (cf. 1J 4:18). St. Basil sees humility as the highest virtue, a ladder to the heights of perfection ${ }^{53}$. St. Alphonsus Liguori adds that "it is a good thing to humiliate oneself before the others, but even better - to accept humiliations we receive from the others, because there is less of our own activity and more of God's work" (The Recipe for Good Life), so they bring a greater spiritual benefit.

Such spiritual auto-formation is written into the space of the "ascesis of weakness" ${ }^{54}$, in the hope that weakness calls towards grace, as

49 H. Witczyk, „Pokorny wotat, i Pan go wystuchat [This poor man cried, and the Lord heard him]" (Ps 34,7a). Model komunikacji diafonicznej w psalmach, Lublin 1997, p. 164.

Cf. Leon XIII, Praktyka pokory, [The practice of humility] transl. S. Gaworek, Warszawa 2006, no. IV.

Ibid., no. XLI.

The Sermon of True Humility and Fear of God, in: Leon XIII, Praktyka pokory, p. 94 .

53 See M. Szram, Cnota pokory $w$ nauczaniu greckich Ojców Kościoła IV wieku, [The Virtue of Humility in the Teaching of the Fourth-Century Greek Fathers], Lublin 2014, p. 72-79.

54 A. Louf, Pokora i postuszeństwo [Humility and obedience], Kraków 2003. 
Teologia duchowości

long as the sinner is contrite. Its antithesis is pride, grown from the focus on oneself and from haughtiness preventing one from a solid discernment of the reality. At the root of pride there is fear, deforming external relations and the internal way of perceiving reality. The "I" emerges from a community of existence, isolates itself and relates to everything in a pretentious way ${ }^{55}$.

In this situation it is helpful to accept the truth about "the humility of God," which gives the courage to come out of isolation and to recognize one's insufficiency. "If God was not humble, His forgiveness would have a doubtful value for us [...] would it not be more proper for us to reject this forgiveness rather than accept it?"56. In this very meaning humility is not an ordinary moral virtue, but a passive virtue, that is a spiritual "disposition to accept what cannot be born either from blood, or from the carnal desire, or from the will of man (Jn 1:13), to accept the Gift which has come down (see. Eph 4:9)"57.

In this respect the Christian practice of "brotherly admonition" (correptio fraterna) is helpful, where pointing out the error is connected with a sincere care about the correction of the errant person's life and not with a tendency to hurt one's neighbour.

St. Benedict lists twelve degrees of humility ${ }^{58}$, seeing its highest dimension in obedience ${ }^{59}$ and considering it an efficient weapon against the pride of Satan.

The ladder thus set up is our life in the world, which the Lord raises up to heaven if our heart is humbled. For we call our body and soul the sides of the ladder, and into these sides our divine vocation has inserted the different steps of humility and discipline we must climb ${ }^{60}$.

A warning against "doing one's own will" ${ }^{61}$ is connected with this dynamic vision. Having ascended all the rungs of the ladder the monk becomes accustomed "to good and finds joy in virtue" ${ }^{2}$, free from the

$55 \quad$ Cf. W. Zatorski, Pokora [Humility], Kraków 2008.

56 F. Varillon, Pokora Boga [God's humility], transl. W. Sukiennicka, Warszawa 1977, p. 158.

$57 \quad$ H. de Lubac, O naturze $i$ tasce [About nature and grace], Kraków 1986, p. 33.

$58 \quad$ Cf. Rule, chapter 7.

$59 \quad$ Ibidem, chapter 5.

60 Ibidem, 7,5-9.

$61 \quad$ Ibidem, Prologue 3.

62 Ibidem, 7,69. 
feeling of exhaustion and renunciation. St. Bernard of Clairvaux in humility sees the warrant of graces and mystical vision of God ${ }^{63}$.

Humility is an efficient antidote for individualism. It makes it possible to appreciate the others and to set oneself free from excessive focus on oneself. It should not be mistaken for the lack of self-dignity or value, or the lack of confidence, since precisely this produces defensive attitude ${ }^{64}$ or even aggression towards the others. Also shyness

or timidity can feign humility, while true humility requires courage, in Teologia order to have sound judgment and to undertake specific actions, even contrary to everybody else's opinion.

Christians, getting rid of pride - the hotbed of all sin - acquire the attitude of Christ (magister humilitatis), who "did not regard equality with God as something to be exploited [...] but humbled himself" (see Phil 2:5-11) and set example (cf. Jn 13:1-17) for human relationships. Authentic humility "is one of the best weapons we have at our disposal" in the fight against our problems (accepting the truth, getting out of egocentrism, excessive care about the others etc.

In the theological sense it also means accepting Christ as the only fundum - foundation, on which beliefs and actions rest. As a consequence, man does not rely on himself and becomes stronger, as St. Bernard of Clairvaux teaches: "Timidity will not be able to slip under the guise of true humility since the soul, the more it distrusts itself in small things, the more hope it has in the power of God, when great and difficult issues arise" ${ }^{65}$.

Key words: Christ-forming, the formation of persons, humility.

\section{Bibliography:}

1. Augustine St., The Sermon of True Humility and Fear of God, [in:] Leon XIII, Praktyka pokory.

2. Benedict XVI, Encyclical to the bishops, priests and deacons men and women religious and all the lay faithful on christian love Deus Caritas est, [God is Love] (25.12.2005).

$63 \quad$ Cf. Tractatus de gradibus humiliatis et superbiae, PL 182, 941-972.

64 Cf. M. Kinzer, Pokora chrześcijanina [Christian humility], transl. S. J. Demscy, Kraków 1996; M. Janukowicz,Pedagogicznykontekstpokory,[Pedagogical context of humility], Częstochowa 2008; C. A. Kustra, Znaczenie pokory w wychowaniu chrześcijańskim w ujęciu ks. Bronisława Markiewicza (1842-1912), [The importance of humility in Christian education by Fr. Bronislaw Markiewicz], Toruń 1998.

65 Myśli św. Bernarda [The Thoughts of St. Bernard], oprac. M. Pachocki, Poznań 1935, p. 142 (fotooffset Poznań 1996). 
Teologia duchowości

3. Benedict XVI, Encyclical to the bishops, priests and deacons men and women religious and all the lay faithful on christian hope: Spes salvi, [In hope we were saved] (30.11.2007).

4. Bernard of Clairvaux, Tractatus de gradibus humiliatis et superbiae, PL 182, 941-972.

5. Congregation for Institutes of Consecrated Life and Societies of Apostolic Life, Instruction Starting Afresh from Christ: A renewed commitment to consecrated life in the third millennium, (19.05.2002).

6. Formacja zakonna, Jerzy W. Gogola OCD (ed.), vol. 1-7, Kraków 1997-2002.

7. Francis, Apostolic Exhortation on the proclamation of the Gospel in today's world: Evangelii gaudium, [English: The Joy of the Gospel], (24.11.2013).

8. Grignion de Montfort L. M., The Treatise of the Perfect Devotion to Our Lady, Electronic Copyright (C) 1998 EWTN.

9. Guardini R., Bóg daleki. Bóg bliski, transl. J. Koźbiał, Poznań 1991.

10. Janukowicz M., Pedagogiczny kontekst pokory, [Pedagogical context of humility], Częstochowa 2008.

11. John Paul II, Apostolic Exhortation of the Lay Faithful in the Church and in the World: Christifideles laici, (30.12.1988).

12. John Paul II, Apostolic Exhortation on the bishop servant of the Gospel of Jesus Christ: Pastores gregis, (16.10.2003).

13. John Paul II, Apostolic Exhortation on the consecrated life and its mission in the Church and in the world: Vita consecrata, (25.03.1996).

14. John Paul II, Apostolic Exhortation on the Formation of Priests in the Circumstances of the Present Day: Pastores dabo vobis, (25.03.1992).

15. John Paul II, Apostolic Exhortation to men and women religious on their consecration in the light of the mystery of redemption: Redemptionis donum, (25.03.1984).

16. John Paul II, Apostolic Letter Novo millennio ineunte, [At the beginning of the new millennium], (6.01.2001).

17. John Paul II, Apostolic Letter on preparation for the Jubilee of the Year 2000: Tertio millenio adveniente, (10.11.1997).

18. John Paul II, Encyclical of the catholic Church regarding certain fundamental questions of the church's moral teaching: Veritatis splendor, [The Splendour of Truth] (6.08.1993).

19. John Paul II, Redemptor hominis Encyclical Letter [The Redeemer of Man], (4.03.1979).

20. Kempys M. J., Rola cnót moralnych $w$ daż̇eniu do petni człowieczeństwa $w$ świetle pism o. Jacka Woronieckiego, [The role of the moral virtues in the pursuit of full humanity in the light of the writings of Jack Woroniecki], Kraków 2005.

21. Kinzer M., Pokora chrześcijanina [Christian humility], transl. S. J. Demscy, Kraków 1996.

22. Kołakowski L., Machovec M., Jesus - Modell des unbedingten Anspruchs an den Menschen, "Theologische Berichte" vol. 7 (1978), Zurich, s. 72-79.

23. Kustra C. A., Znaczenie pokory $w$ wychowaniu chrześcijańskim $w$ ujęciu ks. Bronistawa Markiewicza (1842-1912), [The importance of humility in Christian education by Fr. Bronislaw Markiewicz], Torun 1998. 
24. Leon XIII, Praktyka pokory, [The practice of humility ] transl. S. Gaworek, Warszawa 2006.

25. Louf A., Pokora i postuszeństwo [Humility and obedience], Kraków 2003. 26. Lubac H. de, O naturze i łasce [About nature and grace], Kraków 1986.

27. Myśli św. Bernarda [The Thoughts of St. Bernard], oprac. M. Pachocki, Poznań 1935, (fotooffset Poznań 1996).

28. Nowak A. J., Osobowość sakramentalna, [Sacramental Personality], Lublin $1992,1997$.

29. Nowak A. J., Psychologia eklezjalna [Ecclesial Psychology], Lublin 2005.

30. Nowak A. J., Osoba - fakt i tajemnica, [Person - Fact and Mystery] Rzeszów 2010.

31. Pascal B., Pensees, no. 72, transl. by W.F. Trotter [no. 84 - Polish transl. T. Boy-Żeleński, Warszawa 1989].

32. Paszkowska T., Formacja i godność [Formation and dignity], Kraków 2004.

33. Paul VI, Apostolic Letter on the Occasion of the Eightieth Anniversary of the Encyclical "Rerum Novarum": Octogesima adveniens, (14.05.1971).

34. Ratzinger J., Czas przemian w Europie. Miejsce Kościoła $i$ świata [The Time of change in Europe. The place of the Church and the World], transl. M. Mijalska, Kraków 2005.

35. Sanna I., L'antropologia tra modernitá e postmodernitá, Brescia 2001.

36. Szostek A., Wokót godności, prawdy i miłości. Rozważania etyczne [About Dignity, Truth and Love. Ethical reflections], Lublin 1995.

37. Szram M., Cnota pokory $w$ nauczaniu greckich Ojców Kościoła IV wie$k u$, [The Virtue of Humility in the Teaching of the Fourth-Century Greek Fathers], Lublin 2014

38. Varillon F., Pokora Boga [God's humility], transl. W. Sukiennicka, Warszawa 1977.

39. Vatican Council II's Decree on priestly training: Optatam totius, (28.10.1965).

40. Vatican Council II's Decree on the adaptation and renewal of religious life: Perfectae caritatis, (28.10.1965).

41. Vatican Council II's Decree on the ministry and life of priests: Presbyterorum ordinis, (7.11.1965).

42. Vatican Council II's Pastoral Constitution on the Church in the modern world: Gaudium et spes, (7.12.1965).

43. Vergote A., Jezus Chrystus jako fundament wychowania, "Communio” 11(1991) nr 2, s. 89-97.

44. Witczyk H., "Pokorny wotat, i Pan go wystuchat [This poor man cried, and the Lord heard him]" (Ps 34,7a). Model komunikacji diafonicznej w psalmach, Lublin 1997.

45. Wojtyła K., Miłość i odpowiedzialność [Love and Responsibility], Lublin 2001.

46. Zatorski W., Pokora [Humility], Kraków 2008.

47. Zawada M., Podstawy architektury duchowej. Pokora, [Basics of spiritual architecture. Humility], Kraków 2006. 